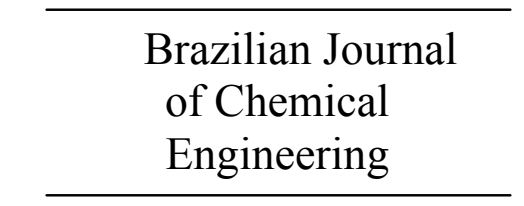

ISSN 0104-6632 Printed in Brazil

Vol. 21, No. 02 pp. 335 - 343, April - June 2004

\title{
DROPLET SIZE IN A RECTANGULAR VENTURI SCRUBBER
}

\author{
M. A. M. Costa, P. R. Henrique, J. A. S. Gonçalves and J.R.Coury* \\ Departamento de Engenharia Química, Universidade Federal de São Carlos, Phone +(55) (16) 260-8264, R.236, \\ Fax +(55) (16) 260-826, Via Washington Luiz, km. 235, 13565-905, São Carlos - SP, Brasil. \\ Email: jcoury@power.ufscar.br
}

(Received: February 13, 2003 ; Accepted: November 10, 2003)

\begin{abstract}
The Venturi scrubber is a device which uses liquid in the form of droplets to efficiently remove fine particulate matter from gaseous streams. Droplet size is of fundamental importance for the scrubber performance. In the present experimental study, a laser diffraction technique was used in order to measure droplet size in situ in a Venturi scrubber with a rectangular cross section. Droplet size distribution was measured as a function of gas velocity $(58.3$ to $74.9 \mathrm{~m} / \mathrm{s})$, liquid-to-gas ratio $\left(0.07\right.$ to $\left.0.27 \mathrm{l} / \mathrm{m}^{3}\right)$, and distance from liquid injection point (64 to $173 \mathrm{~mm}$ ). It was found that all these variables significantly affect droplet size. The results were compared with the predictions from correlations found in the literature.

Keywords: Venturi scrubber, droplet size, laser diffraction.
\end{abstract}

\section{INTRODUCTION}

Venturi scrubbers are gas-cleaning devices which remove dust by collecting them in droplets. A schematic representation of a typical Venturi scrubber is shown in Figure 1. The droplets are formed by atomization of the liquid at the Venturi throat, which occurs when the liquid comes into contact with the high-velocity gas.

Inertial impact with the droplets is the main collection mechanism for dust particles with diameters over $0.5 \mu \mathrm{m}$. For particles under $0.1 \mu \mathrm{m}$, the collection mechanism is not yet clear, though it is probable that a mechanism involving turbulent diffusion predominates. Collection efficiency is a complex function of many parameters, including droplet size and concentration distribution, liquid-togas ratio, jet penetration, and liquid film fraction. In particular, droplet size is of fundamental importance for the performance of the Venturi scrubber (Mayinger and Neumann, 1978). A spray of small droplets provides a higher surface area per volume of liquid than a spray of large drops, which favors the collection of dust. On the other hand, small droplets accelerate faster, so the average relative velocity between the dust and the droplets, which is directly proportional to the collection efficiency of a single droplet, is lower.

The air-blast atomization in Venturi scrubbers produces a large distribution of droplet sizes. The Sauter mean diameter $\left(\mathrm{D}_{32}\right)$, expressing the average ratio between the volume and the surface area of the droplets, is the most appropriate mean diameter to represent the size distribution in Venturi scrubbers.

A droplet size distribution can be expressed in terms of mass, volume, surface area, or number. One of the functions most frequently utilized to represent a volumetric size distribution is the Rosin-Rammler two-parameter function:

$$
1-\phi=\exp \left[-\left(\frac{D_{d}}{X}\right)^{n}\right]
$$

*To whom correspondence should be addressed 
where $\phi$ is the fraction of the total volume occupied by droplets with a diameter smaller than $\mathrm{D}_{\mathrm{d}}$ and $\mathrm{X}$ and $\mathrm{n}$ are the function parameters. Parameter $\mathrm{n}$ gives a measure of the spread of the distribution, i.e., the higher the value of $\mathrm{n}$, the more uniform or monodispersed is the distribution. The parameter $\mathrm{X}$ is defined as the diameter such that $63.2 \%$ of the total volume is formed of droplets smaller than X.

Two correlations have frequently been used to estimate droplet size in Venturi scrubbers: the classic correlation proposed by Nukiyama and Tanasawa (1938) and the correlation of Boll et al. (1974). Nukiyama and Tanasawa (1938) used the method of collecting droplets on slides in order to study their size distribution. They varied gas velocity between 73 and $230 \mathrm{~m} / \mathrm{s}$ and the liquid-to-gas ratio (L/G) between 0.08 and $1.01 / \mathrm{m}^{3}$. As a result of their experiments, they proposed the following correlation:

$$
\begin{aligned}
& \mathrm{D}_{32}=\frac{0.585}{\mathrm{v}_{\mathrm{r}}} \sqrt{\frac{\sigma}{\rho_{1}}}+1.683 \times 10^{-3} \\
& \left(\frac{\mu_{1}}{\sqrt{\sigma \rho_{1}}}\right)^{0.45}\left(\frac{1000 \mathrm{Q}_{1}}{\mathrm{Q}_{\mathrm{g}}}\right)^{1.5}
\end{aligned}
$$

where $v_{\mathrm{r}}$ is the relative axial velocity between gas and liquid at the atomization point (usually the jet injection point); $\sigma, \rho_{1}$ and $\mu_{1}$ are the surface tension, liquid density and liquid viscosity, respectively; and $\mathrm{Q}_{1}$ and $\mathrm{Q}_{\mathrm{g}}$ are the liquid and gas volumetric flow rates, respectively. All the symbols in Equation (2) are in SI units, and the resulting Sauter mean diameter is in meters.

Boll et al. (1974) reported droplet size measurements in a Venturi scrubber operating with liquid-to-gas ratios varying from 0.6 to $2.41 / \mathrm{m}^{3}$. The authors used the attenuation of a monochromatic light passing through a spray in order to measure the size of the droplets. This method does not give a size distribution, but rather only a mean diameter. The authors proposed the following correlation for the Sauter Mean Diameter (SI units must be used):

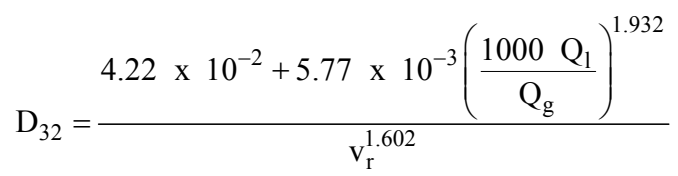

The convenience of using a single mean diameter to represent the wide size distribution that occurs in Venturi scrubbers has been criticized by Bayvel (1982) and Fathikalajahi et al. (1996). Bayvel (1982) showed that a calculated overall collection efficiency could be very different if the size distribution instead of a single mean diameter were used.

Many different methods have been used for droplet size measurements (for a review of those methods, see Azzopardi, 1979). Each method has advantages and disadvantages. Nonetheless, the laser diffraction method, which allows in situ measurement, has become one of the most reliable (Zaidi et al., 1998). For droplets in the size range and velocities typically found in Venturi scrubbers, this method is certainly more reliable than those based on photographs, collection of droplets on slides, or light attenuation, which were the main methods available to most previous researchers.

The general principle of the laser diffraction method is that the diffraction pattern of a laser beam incident on a droplet is related to droplet size. Swithenbank et al. (1976) developed a system to make use of this principle, and it has been exploited commercially by some analytical equipment manufacturers. The Malvern Particle Sizer, which is able to measure the velocity, concentration, and size distribution of a moving spray, is one of the better known pieces of equipment of this kind.

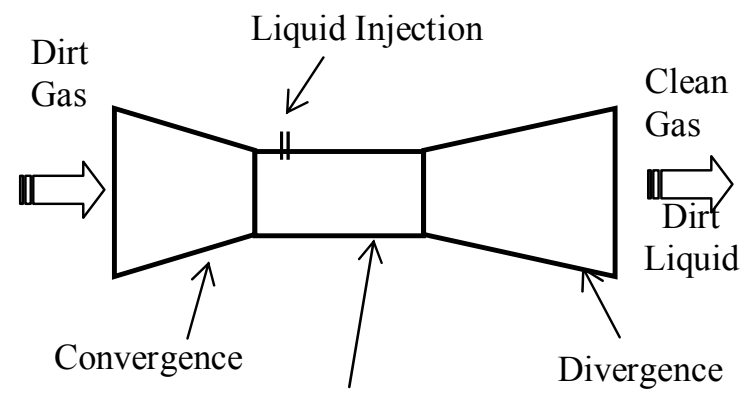

Throat

Figure 1: Schematic representation of a typical Venturi scrubber. 


\section{MATERIALS AND METHODS}

This experimental study utilized the method of laser diffraction, described briefly above, to measure droplet size in a rectangular Venturi scrubber. The Malvern Spray Tech, which is available commercially, was used. This analytical equipment has a laser beam transmitter and a receptor. The receptor has a number of concentric rings which detect light intensity. Initially, most of the light is received in the central ring. As the spray passes between the transmitter and the receptor, some light is reflected and some diffracted in a way that the total light intensity available decreases sharply in the central ring and increases in the other rings. The receptor is attached to a computer which transforms the light intensity signal into a droplet-size distribution. Mean diameters, such as $\mathrm{D}_{32}$, are calculated automatically by the Malvern software from this distribution. If $\mathrm{x}_{\mathrm{i}}$ and $\mathrm{D}_{\mathrm{di}}$ are the mass fraction and the average droplet diameter of each size interval and $m$ is the number of size intervals into which the distribution was divided, the Sauter mean diameter is given by:

$$
\mathrm{D}_{32}=\frac{1}{\sum_{\mathrm{i}=1}^{\mathrm{m}}\left(\mathrm{x}_{\mathrm{i}} / \mathrm{D}_{\mathrm{di}}\right)}
$$

Care was taken to avoid some well known measurement problems associated with the laser diffraction technique. Thus, the cut-off distance of the receptor was avoided and the obscuration was monitored for each analysis. The small $\mathrm{L} / \mathrm{G}$ ratios used guaranteed that the volumetric fraction of the dispersed phase was always within the allowable range.

The Venturi scrubber used, displaced horizontally, has a rectangular cross section $35 \mathrm{~mm}$ tall by $24 \mathrm{~mm}$ wide. Water was injected through a single orifice, with a $1 \mathrm{~mm}$ diameter, located on the top wall of the throat, $15 \mathrm{~mm}$ beyond the beginning of the throat. Gas velocity was 58.3, 66.6 and 74.9 $\mathrm{m} / \mathrm{s}$, and the liquid-to-gas ratio was $0.07,0.17$ and $0.27 \mathrm{l} / \mathrm{m}^{3}$. The droplets were measured at three positions along the Venturi throat. The first position (D1) was located $64 \mathrm{~mm}$ after injection; the second (D2), $118 \mathrm{~mm}$; and the third (D3), $173 \mathrm{~mm}$.

One of the main difficulties in experiments of this kind is to provide good optical access to the interior of the equipment without interfering too much in the flow and at the same time allow the laser beam to go undisturbed from transmitter to receptor. For this purpose, a special test section, shown in Figure 2, was built. The throat of the scrubber was sectioned into modules in such a way that the test section could be inserted anywhere between any two modules.

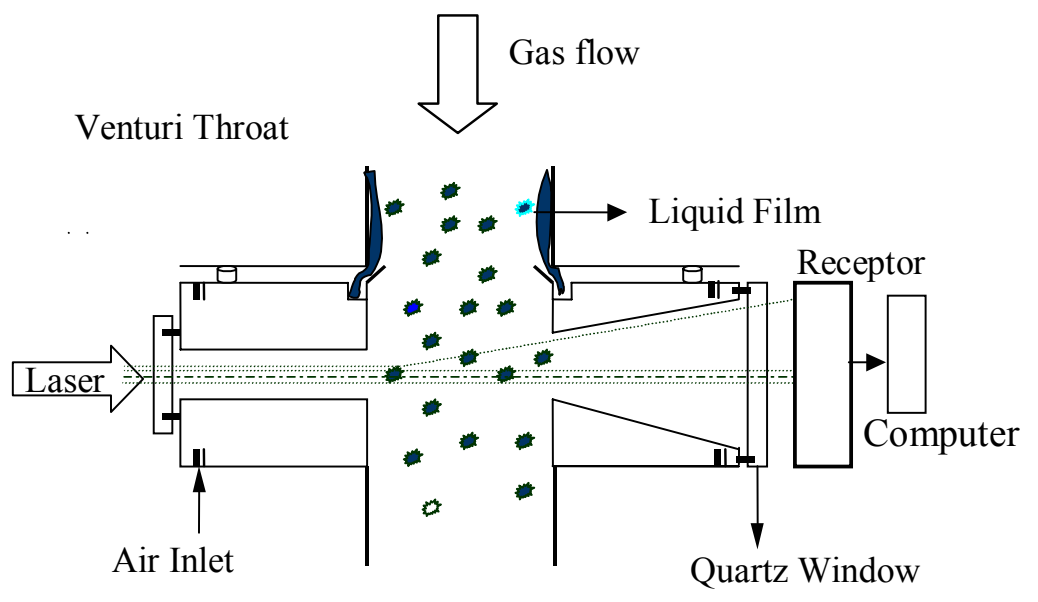

Figure 2: Schematic representation of the test section for gaining optical access to the Venturi throat. 
The test section had a system to remove the liquid film flowing on the scrubber walls just before the point of measurement. Removal of the film was regulated by a valve, in such a way that all the film, but only the film, was removed. Conical holes provided a passage to the beam. Special quartz glass covered the holes. Compressed air was injected close to the quartz glass windows in order to protect them from droplets. Fine foam covered the conical holes to absorb the liquid that tended to deposit on the walls, hindering the reentrainment or reatomization of this liquid. Similar test sections have been used with success by other authors (Fernández Alonso et al., 2001).

At the beginning of each experiment, the lenses and windows were cleaned, the transmitter and receptor aligned, and the background luminosity measured.

\section{RESULTS AND DISCUSSION}

The measured $\mathrm{D}_{32}$ and the corresponding calculated Rosin-Rammler $\mathrm{X}$ and $\mathrm{n}$ parameters for all the operational conditions and different measurement positions in these experiments are presented in Table 1, which for purposes of comparison also contains the $\mathrm{D}_{32}$ estimated with the Nukiyama and Tanasawa (1938) and Boll et al. (1974) correlations.

The effect of gas velocity on droplet size can be observed in Figures 3 and 4. In most cases, an increase in gas velocity caused a decrease in droplet size. This is in qualitative agreement with both the Nukiyama and Tanasawa (1938) and Boll et al. (1974) experiments and correlations, and can be explained by the fact that with the increase in the gas velocity, more energy is available to increase the total surface area required for a finer spray. The exceptions to this general trend reported in this study (Table 1 and Figure 4) illustrate the complexity of the phenomenon under investigation. Gas velocity affects jet penetration and turbulent intensity, which in turn affects droplet preferential deposition and coalescence, both of which could explain the observed unexpected increase in $\mathrm{D}_{32}$ in some cases.

The effect of the liquid-to-gas ratio (L/G) can be seen in Figure 5. An increase in L/G usually caused a decrease in droplet size. Working with higher $\mathrm{L} / \mathrm{G}$ ratios than in the present experiments, both Nukiyama and Tanasawa (1938) and Boll et al.
(1974) found that droplet size increased slightly with L/G. Also working with higher L/G ratios, Fernández Alonso et al. (2001) reported no significant influence of $\mathrm{L} / \mathrm{G}$ on droplet diameter. Because of the different ranges of $\mathrm{L} / \mathrm{G}$ ratio utilized, these results cannot be directly compared. However, the present results may indicate that for small $\mathrm{L} / \mathrm{G}$ ratios, droplet size is significantly influenced by $\mathrm{L} / \mathrm{G}$ ratio, a behavior that the available correlations fail to predict.

A comparison of the present results with the predictions of the correlations of Nukiyama and Tanasawa (1938) and Boll et al. (1974) show a slightly better overall performance for the more recent correlation, with an average percentage deviation of $39 \%$ against $45 \%$. The correlation of Boll et al. (1974) performed better when compared to the results for higher $\mathrm{L} / \mathrm{G}$ ratios. For $\mathrm{L} / \mathrm{G}=0.27$ $1 / \mathrm{m}^{3}$, the average percentage deviation was $25 \%$; for $\mathrm{L} / \mathrm{G}=0.17 \mathrm{1} / \mathrm{m}^{3}$, the average deviation was $34 \%$ and for the smallest $\mathrm{L} / \mathrm{G}$ ratio the deviation was $58 \%$.

Cumulative curves and histograms are presented in Figures 6 to 10 for some of the operational conditions used in this study. The full lines in those figures contain the raw (model independent) results as measured by the Malvern. The dotted lines represent results calculated by imposing a RosinRammler distribution. In each case, the $X$ and $n$ parameters were found by the least squares method, minimizing the distance between the raw results and the calculated results. Several statistical functions have been used to describe spray distributions, the Rosin-Rammler function being one of the most common (Lefebvre, 1989).

The change in droplet size distribution as the spray moves along the scrubber can be seen in Figure 11 for a gas velocity of $58.3 \mathrm{~m} / \mathrm{s}$ and a liquidto-gas ratio of $0.07 \mathrm{1} / \mathrm{m}^{3}$. In this figure, the modelindependent results measured at two different positions (D1 and D3) were superimposed. As the liquid moves from D1 to D3, a movement to the right in the droplet size distribution can be observed, indicating an increase in the size of the droplets. The same behavior was reported by Gonçalves (2000) for a cylindrical Venturi scrubber. A combination of factors, including preferential deposition (by turbulent diffusion) of the smaller droplets, evaporation/condensation, and coalescence of droplets, may contribute to this. This last factor is probably predominant. 
Table 1: Measured Sauter Mean Diameter $\left(D_{32}\right)$ and calculated $X$ and $n$ Rosin-Rammler parameters, compared with the $D_{32}$ estimated by the Nukiyama and Tanasawa

(1938) and Boll et al. (1974) correlations.

Position D1 $=64 \mathrm{~mm}$ after injection point

\begin{tabular}{|c|c|c|c|c|c|c|}
\hline $\mathbf{V g}(\mathbf{m} / \mathbf{s})$ & $\begin{array}{c}\mathbf{L} / \mathbf{G} \\
\left(\mathbf{l} / \mathbf{m}^{\mathbf{3}}\right)\end{array}$ & $\mathbf{X}(\boldsymbol{\mu \mathbf { m } )}$ & $\mathbf{n}$ & $\mathbf{D}_{\mathbf{3 2}}{ }^{*} \mathbf{E x p}$ & $\mathbf{D}_{\mathbf{3 2}}{ }^{*} \mathbf{N T}$ & $\mathbf{D}_{\mathbf{3 2}}{ }^{*} \mathbf{B o l l}$ \\
\hline 58.3 & 0.07 & 238.2 & 2.06 & 133.9 & 86.1 & 62.6 \\
58.3 & 0.17 & 167.2 & 1.49 & 71.6 & 87.6 & 62.9 \\
58.3 & 0.27 & 113.9 & 1.31 & 44.9 & 89.7 & 63.3 \\
66.6 & 0.07 & 215.9 & 1.82 & 110.8 & 75.4 & 50.6 \\
66.6 & 0.17 & 200.0 & 1.80 & 105.2 & 76.9 & 50.8 \\
66.6 & 0.27 & 112.1 & 1.44 & 47.2 & 79.1 & 51.1 \\
74.9 & 0.07 & 182.3 & 1.90 & 84.2 & 67.1 & 41.9 \\
74.9 & 0.17 & 200.0 & 1.80 & 98.0 & 68.7 & 42.1 \\
74.9 & 0.27 & 116.8 & 1.45 & 50.3 & 70.8 & 42.3 \\
\hline
\end{tabular}

Position D2 $=118 \mathrm{~mm}$ after injection point

\begin{tabular}{|c|c|c|c|c|c|c|}
\hline $\mathbf{V g}(\mathbf{m} / \mathbf{s})$ & $\begin{array}{c}\mathbf{L} / \mathbf{G} \\
\left(\mathbf{l} / \mathbf{m}^{\mathbf{3}}\right)\end{array}$ & $\mathbf{X}(\boldsymbol{\mu \mathbf { m } )}$ & $\mathbf{n}$ & $\begin{array}{c}\mathbf{D}_{\mathbf{3 2}}{ }^{*} \\
\mathbf{E x p}\end{array}$ & $\mathbf{D}_{\mathbf{3 2}}{ }^{*} \mathbf{N T}$ & $\mathbf{D}_{\mathbf{3 2}}{ }^{*} \mathbf{B o l l}$ \\
\hline 58.3 & 0.07 & 271.2 & 2.42 & 168.1 & 86.1 & 62.6 \\
58.3 & 0.17 & 159.5 & 1.73 & 79.6 & 87.6 & 62.9 \\
58.3 & 0.27 & 179.7 & 1.51 & 72.6 & 89.8 & 63.3 \\
66.6 & 0.07 & 225.2 & 2.04 & 123.8 & 75.4 & 50.6 \\
66.6 & 0.17 & 176.8 & 1.66 & 78.7 & 76.9 & 50.8 \\
66.6 & 0.27 & 79.7 & 1.56 & 37.4 & 79.1 & 51.1 \\
74.9 & 0.07 & 200.0 & 1.80 & 98.4 & 67.1 & 41.9 \\
74.9 & 0.17 & 186.4 & 1.72 & 83.4 & 68.7 & 42.1 \\
74.9 & 0.27 & 90.0 & 1.80 & 35.1 & 70.8 & 42.3 \\
\hline
\end{tabular}

Position D3 = $173 \mathrm{~mm}$ after injection point

\begin{tabular}{|c|c|c|c|c|c|c|}
\hline $\mathbf{V g}(\mathbf{m} / \mathbf{s})$ & $\begin{array}{c}\mathbf{L} / \mathbf{G} \\
\left(\mathbf{l} / \mathbf{m}^{\mathbf{3}}\right)\end{array}$ & $\mathbf{X}(\boldsymbol{\mu \mathbf { m } )}$ & $\mathbf{n}$ & $\mathbf{D}_{\mathbf{3 2}}{ }^{*} \mathbf{E x p}$ & $\mathbf{D}_{\mathbf{3 2}}{ }^{*} \mathbf{N T}$ & $\mathbf{D}_{\mathbf{3 2}}{ }^{*} \mathbf{B o l l}$ \\
\hline 58.3 & 0.07 & 292.5 & 2.53 & 170.8 & 86.2 & 62.6 \\
58.3 & 0.17 & 135.5 & 1.65 & 65.9 & 87.4 & 62.9 \\
58.3 & 0.27 & 147.1 & 1.53 & 66.7 & 89.7 & 63.3 \\
66.6 & 0.07 & 251.9 & 2.24 & 120.4 & 75.4 & 50.6 \\
66.6 & 0.17 & 167.5 & 1.57 & 73.0 & 76.9 & 50.8 \\
66.6 & 0.27 & 79.9 & 1.55 & 37.8 & 79.1 & 51.1 \\
74.9 & 0.07 & 242.8 & 1.76 & 104.5 & 67.7 & 41.9 \\
74.9 & 0.17 & 176.3 & 1.59 & 74.8 & 68.7 & 42.1 \\
74.9 & 0.27 & 75.78 & 1.45 & 28.4 & 70.8 & 42.3 \\
\hline
\end{tabular}

*Diameters are shown in $\mu \mathrm{m}$. 


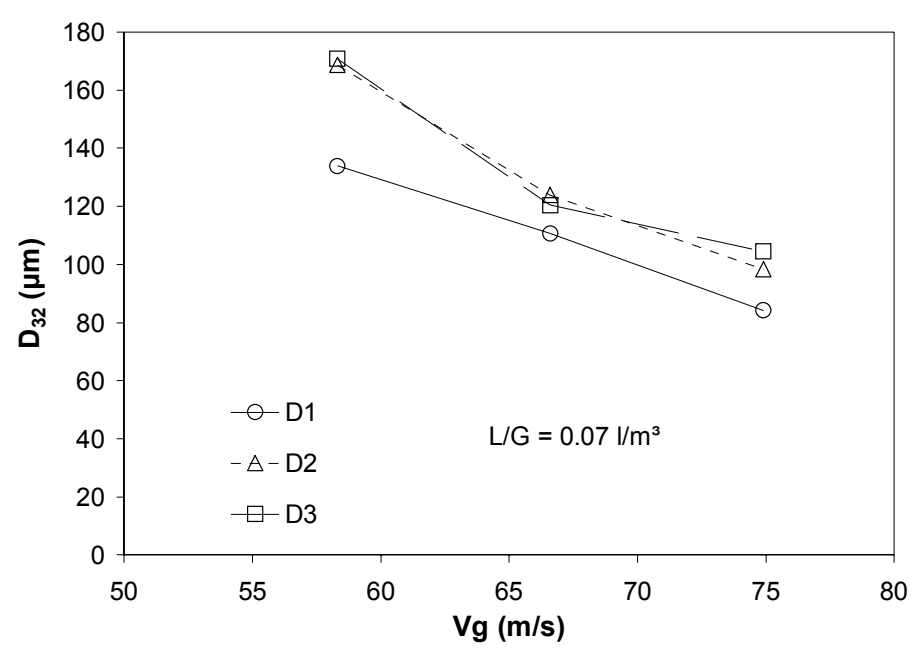

Figure 3: Variation in $D_{32}$ with gas velocity for positions $D 1$, D2 and $D 3 . \mathrm{L} / \mathrm{G}=0.07 \mathrm{l} / \mathrm{m}^{3}$.

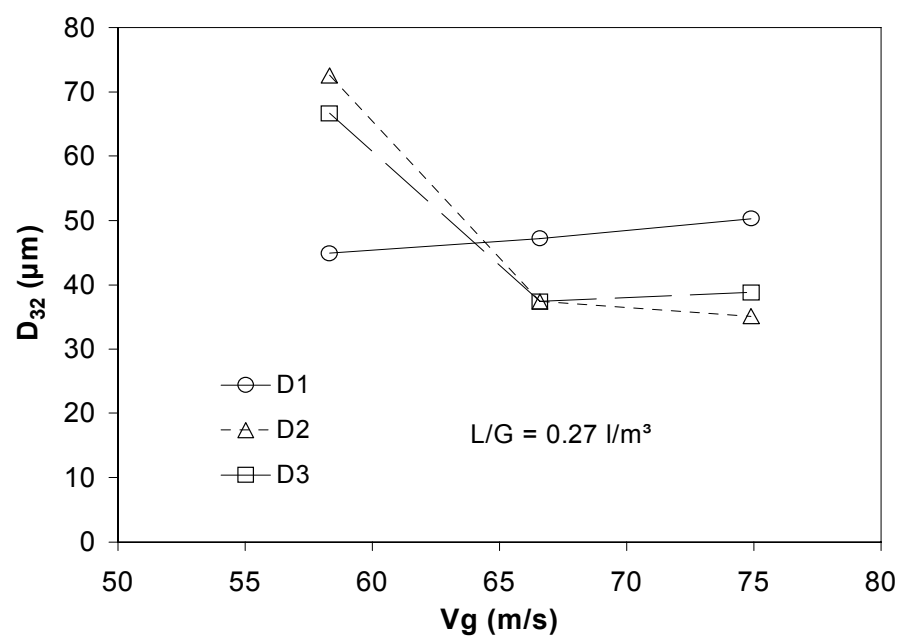

Figure 4: Variation in $D_{32}$ with gas velocity for positions $D 1, D 2$ and $D 3 . ~ L / G=0.271 / \mathrm{m}^{3}$.

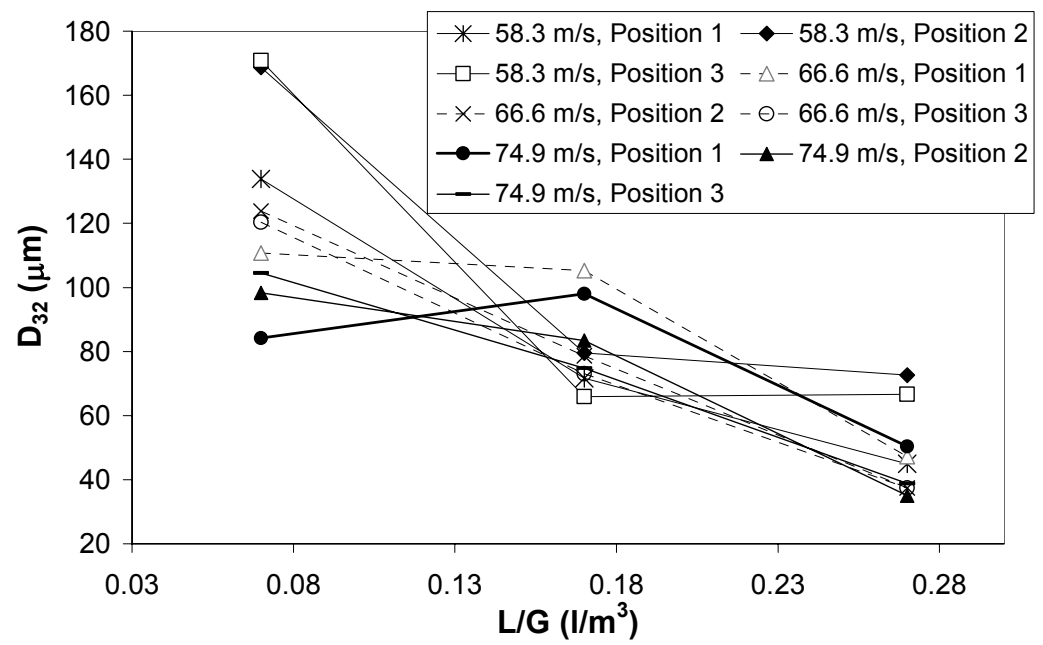

Figure 5: Variation in $D_{32}$ with $L / G$ ratio. 


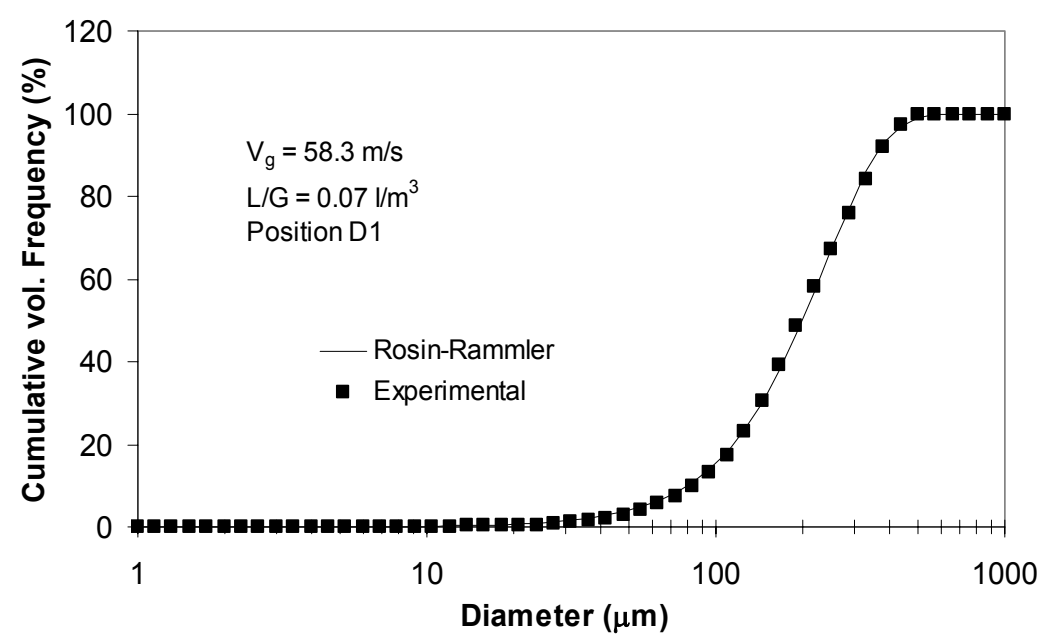

Figure 6: Cumulative droplet size distribution. $\mathrm{Vg}=58.3 \mathrm{~m} / \mathrm{s}, \mathrm{L} / \mathrm{G}=0.07 \mathrm{1} / \mathrm{m}^{3}$, position D1.

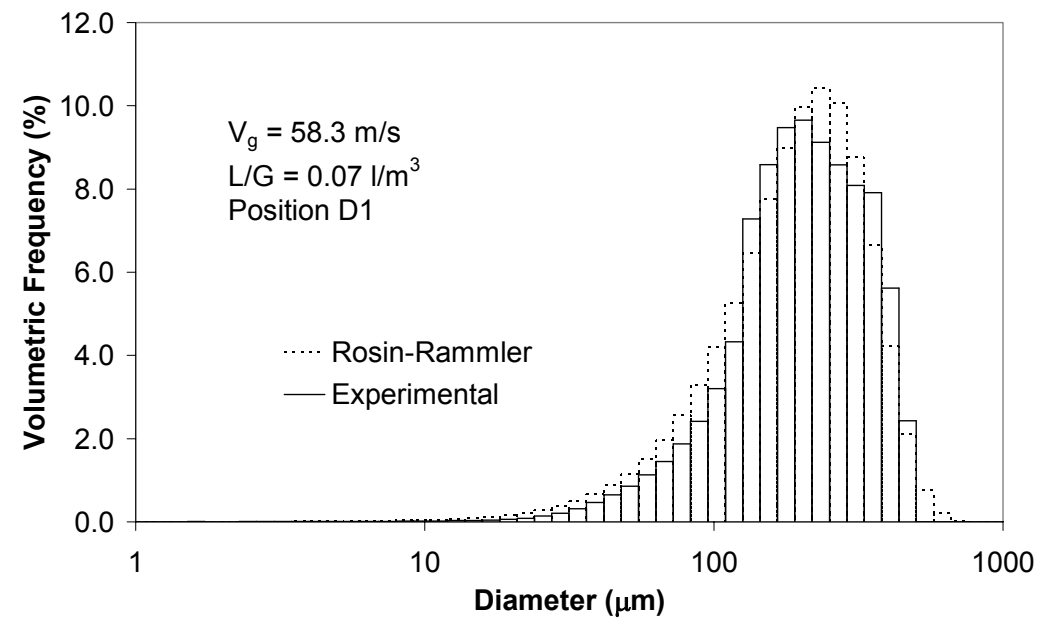

Figure 7: Droplet size distribution histogram. $\mathrm{Vg}=58.3 \mathrm{~m} / \mathrm{s}, \mathrm{L} / \mathrm{G}=0.07 \mathrm{1} / \mathrm{m}^{3}$, position D1.

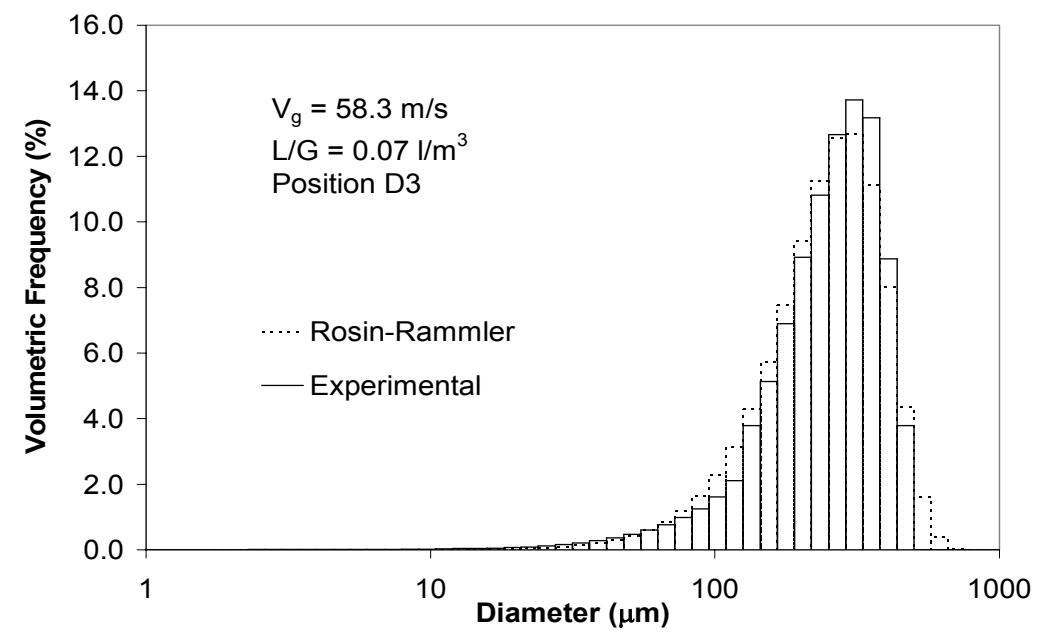

Figure 8: Droplet size distribution histogram. $\mathrm{Vg}=58.3 \mathrm{~m} / \mathrm{s}, \mathrm{L} / \mathrm{G}=0.07 \mathrm{l} / \mathrm{m}^{3}$, position D3. 


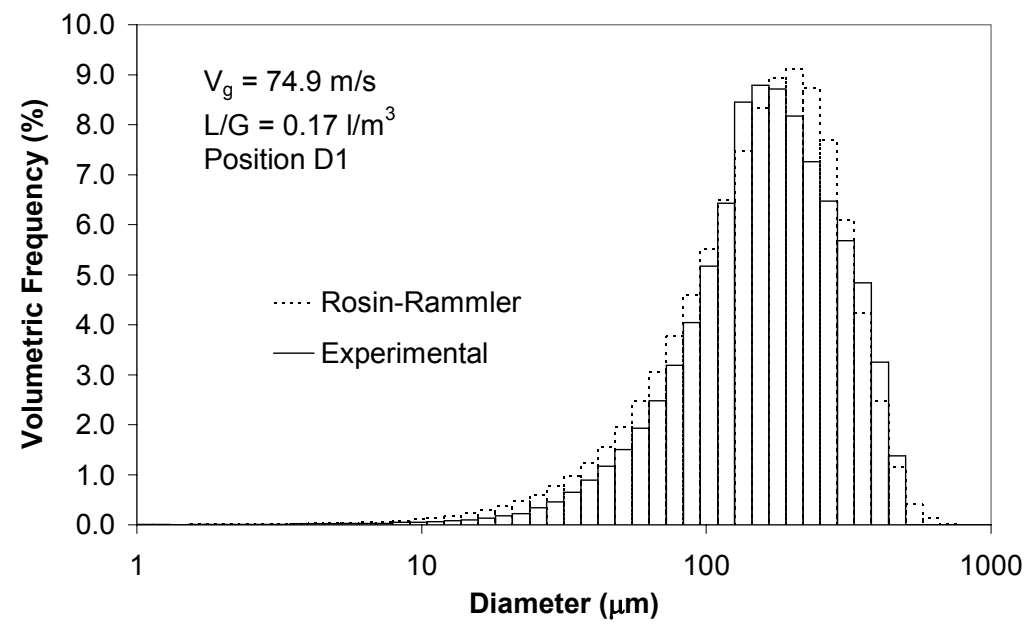

Figure 9: Droplet size distribution histogram. $\mathrm{Vg}=74.9 \mathrm{~m} / \mathrm{s}, \mathrm{L} / \mathrm{G}=0.17 \mathrm{l} / \mathrm{m}^{3}$, position D1.

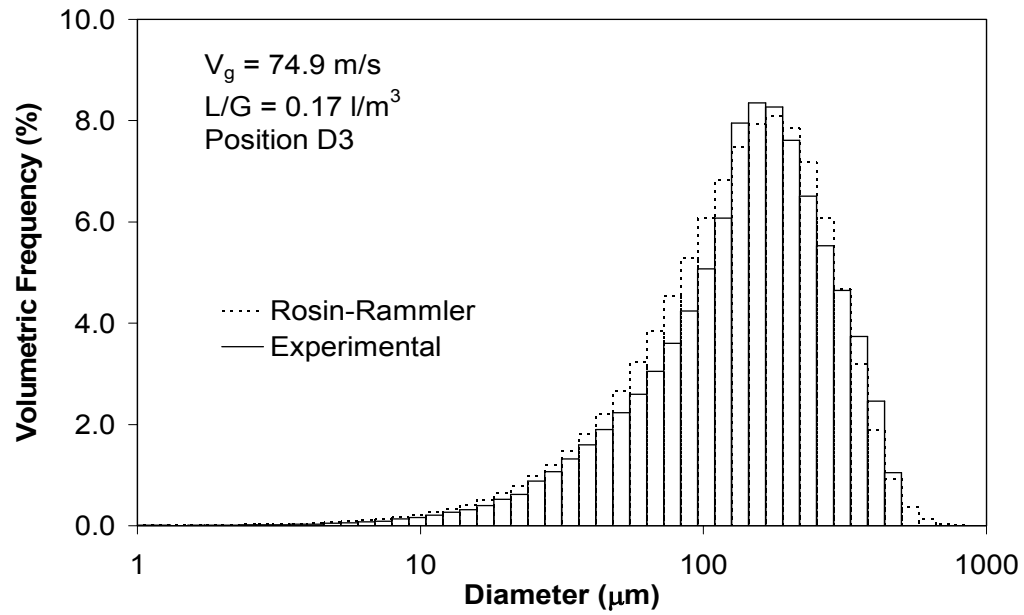

Figure 10: Droplet size distribution histogram. $\mathrm{Vg}=74.9 \mathrm{~m} / \mathrm{s}, \mathrm{L} / \mathrm{G}=0.17 \mathrm{l} / \mathrm{m}^{3}$, position $\mathrm{D} 3$.

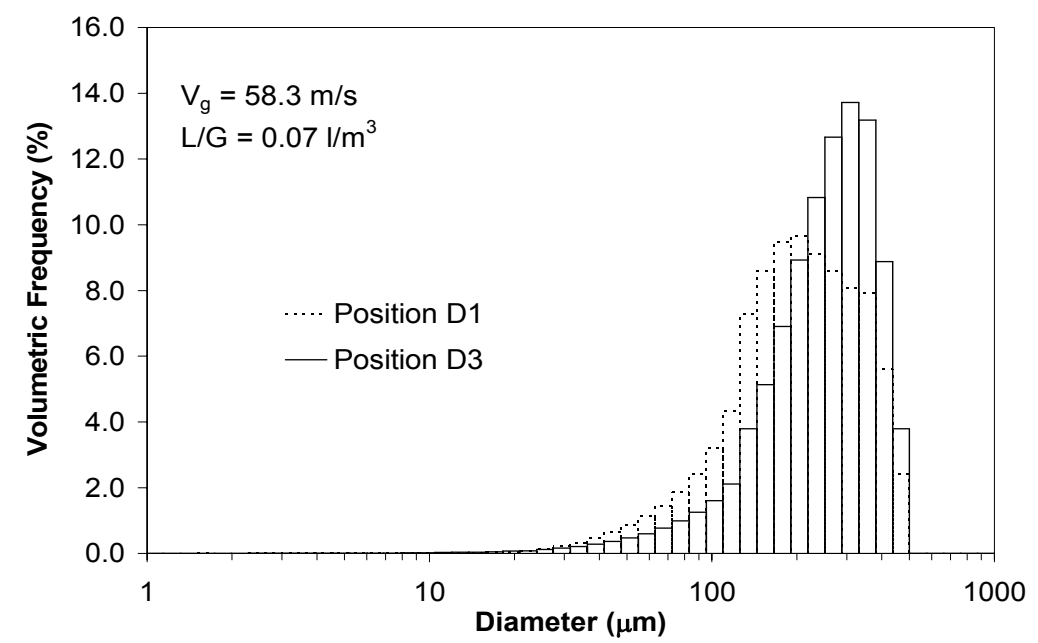

Figure 11: Variation in droplet size distribution with distance in the Venturi scrubber. $\mathrm{Vg}=58.3 \mathrm{~m} / \mathrm{s}, \mathrm{L} / \mathrm{G}=0.07 \mathrm{l} / \mathrm{m}^{3}$. 


\section{CONCLUSIONS}

The in situ experimental technique used in these experiments is generally regarded as the most reliable one available for size measurement of droplets of size ranges and velocities usually found in Venturi scrubbers. The use of this technique offers an advantage over the methods used by most previous authors. The results reported above allow the following conclusions to be drawn.

Gas velocity was a major variable influencing droplet size in Venturi scrubbers.

Droplet size generally diminished with an increase in gas velocity.

For the operational conditions utilized, in particular very small L/G ratios, droplet size usually diminished with an increase in the $\mathrm{L} / \mathrm{G}$ ratio.

Droplet size usually increased with distance from the liquid injection point.

Neither the correlation of Nukiyama and Tanasawa (1938) nor that of Boll et al. (1974) satisfactorily represented these results.

\section{ACKNOWLEGEMENTS}

The authors are grateful to FAPESP, PRONEX, FINEP and CNPq for their financial support.

\section{NOMENCLATURE}

$\begin{array}{ll}\mathrm{D} 1, \mathrm{D} 2, \mathrm{D} 3 & \begin{array}{l}\text { Distance along Venturi axis from liquid } \\ \text { injection point, } \mathrm{m}\end{array} \\ \mathrm{D}_{32} & \text { Sauter mean diameter, } \mathrm{m} \\ \mathrm{D}_{\mathrm{d}} & \text { Droplet diameter, } \mathrm{m} \\ \mathrm{L} / \mathrm{G} & \text { Liquid-to-gas ratio, } 1 / \mathrm{m}^{3} \\ \mathrm{n} & \text { Parameter in Rosin-Rammler statistical } \\ & \text { function, dimensionless } \\ \mathrm{Q}_{\mathrm{g}} & \text { Gas volumetric flow rate, } \mathrm{m}^{3} / \mathrm{s} \\ \mathrm{Q}_{1} & \text { Liquid volumetric flow rate, } \mathrm{m}^{3} / \mathrm{s} \\ \mathrm{V}_{\mathrm{g}} & \text { Gas velocity, m/s } \\ \mathrm{V}_{\mathrm{r}} & \text { Relative axial velocity between gas and } \\ & \text { liquid, m/s } \\ \mathrm{X} & \text { Mass fraction, dimensionless } \\ \mathrm{X} & \text { Parameter in Rosin-Rammler statistical } \\ & \text { function, } \mathrm{m}\end{array}$

\section{Greek Letters}

$\sigma \quad$ Surface tension, $\mathrm{kg} / \mathrm{s}^{2}$ $\mu_{1} \quad$ Liquid viscosity, $\mathrm{kg} / \mathrm{m} . \mathrm{s}$

$\rho_{1} \quad$ Liquid density, $\mathrm{kg} / \mathrm{m}^{3}$

\section{REFERENCES}

Azzopardi, B.J., Measurement of Drop Sizes, Journal of Heat and Mass Transfer, vol. 22, pp. 12451279, 1979.

Bayvel, L.P., The Effect of Polydispersity of Drops on the Efficiency of a Venturi Scrubber, Transactions of the Institution of Chemical Engineers, vol. 60, pp. 31-34, 1982.

Boll, R.H., Flais, L.R., Maurer, P.W. and Thompson, W.L., Mean Drop Size in a Full Scale Venturi Scrubber via Transmissometer, Journal of the Air Pollution Control Association, vol. 24, pp. 934938, 1974.

Fathikalajahi, J., Talaie M.R. and Taheri M., Theoretical Study of Nonuniform Droplet Concentration Distribution on Venturi Scrubber Performance, Particulate Science and Technology, vol. 14, pp. 153-164, 1996.

Fernández Alonso, D., Gonçalves, J.A.S., Azzopardi, B.J. and Coury, J.R., Drop Size Measurements in Venturi Scrubbers, Chemical Engineering Science, vol. 56, pp. 4901-4911, 2001.

Gonçalves, J.A.S., Aspectos da modelagem matemática de lavadores Venturi, Ph.D. diss., Federal University of São Carlos, 2000.

Lefebvre, A.H., Atomization and Sprays, New York, Hemisphere Publishing Corporations, 1989.

Mayinger, F. and Neumann, M., Dust Collection in Venturi Scrubbers, German Chemical Engineering, vol. 1, pp. 289-293, 1978.

Nukiyama, S. and Tanasawa, Y., Experiment on Atomization of Liquid by Means of Air Stream, Transactions of the Society of Mechanical Engineers - Japan, vol. 4, no. 14, pp. 86-93, 1938.

Swithenbank, J., Beer, J.M., Taylor, D.S., Abbot, D. and MacCreath, G.C., A Laser Diagnostic Technique for the Measurement of Droplet and Particle Size Distribution - Experimental Diagnostics in Gas Phase Combustion Systems, Progress in Astronaut and Aeronauts, vol. 53, pp. 421-447, 1976.

Zaidi, S.H., Altunbas, A. and Azzopardi, B.J., A Comparative Study of Phase Doppler and Laser Diffraction Techniques to Investigate Drop Sizes in Annular Two-phase Flow, Chemical Engineering Journal, vol. 71, pp. 135-143, 1998. 